\title{
WHEN DO WOMEN MAKE A BETTER TABLE? EXAMINING THE INFLUENCE OF WOMEN DIRECTORS ON FAMILY FIRM'S CORPORATE SOCIAL PERFORMANCE
}

\section{Cristina Cruz, Rachida Justo, Martín Larraza-Kintana}

\begin{abstract}
Our paper seeks to further understand the influence of gender board diversity on firms' corporate social performance (CPS) in the context of publicly-held family firms. Grounded on corporate governance and family firm literature, we argue that the influence of women directors on CSP will be contingent on their relative power and legitimacy within the board, and that such dynamics are particularly important in family firm boardrooms. Our empirical results show that increases in CSP associated to the presence of women in the boards of family firms are due mainly to the presence of outsider nonfamily and insider family women directors. Implications for the theory of family firms are discussed.
\end{abstract}




\section{INTRODUCTION}

Mirroring its increasing prevalence and visibility within corporations (Wang et al., 2016), research about corporate social responsibility (CSR) has grown significantly during the last two decades (Aguinis and Galvas, 2012). Most of the research on this subject has explored the connection between CSR and corporate financial performance (Rowley \& Berman, 2000), revealing that the link between the two is uncertain at best (Peloza, 2009). Given the elusiveness of a firm's instrumental motivation as a predictor of CSR, scholars are increasingly searching for alternative explanations to account for why some firms are more eager to adopt social practices than others, that is to say, why some firms have higher corporate social performance (CSP). Among the factors identified, research has recently emphasized the pivotal role of female directors (Rao and Tilt, 2016), given the growing normative movement towards gender diversity on boards of directors (e.g. European Commission, 2010), and the extant evidence showing that female directors tend to exhibit a special sensitivity towards social issues such as CSR (Boulouta, 2013).

Despite some important progress, evidence regarding the influence of gender diversity on CSP has been somewhat inconclusive (Rao and Tilt, 2016). In addition, existing literature on the subject often relies on a debatable premise, which is that all female directors possess the same level of influence on a firm's strategy. Yet, evidence shows that it is unlikely that boards can consistently and uniformly leverage female directors' contributions (Terjesen and Sealy, 2016). Previous studies on board diversity show that female directors' power, or their ability to exercise their will (Filkenstein, 1992), is contingent on the political context in which the board operates. Further, because women on corporate boards are still relatively rare, their legitimacy as directors is often challenged (Elstad and Ladegard, 2010). Hence, female directors' power and legitimacy to influence boards seems to represent a missing piece in the narrative around firms' CSP. 
Our research aims to address this gap by uncovering the different categories of female directors and their corresponding influence on pushing the CSR agenda and improve the firm's CSP. Building upon corporate governance literature on board composition (Baysinger and Hoskisson, 1990) and executive power (Finkelstein, 1992), we argue that women's leverage regarding CSR depends upon their relative legitimacy and power to influence decision-making in the boardroom.

We focus specifically upon family firms, which represent an ideal context to investigate this relationship for two main reasons. First, the impact of family ownership on CSP is still open to debate. Many argue that the non-economic rationales that drive family owners' decision-making lead them to enact socially responsible behaviors (Berrone et al., 2010). Others suggest that family firms are heterogeneous in their social orientations (Cruz et al., 2014). Family firms therefore appear to offer a suitable setting for examining the boundary conditions that are conducive to higher levels of CSP. In this sense, it is worth noting that while family scholars have followed the broader trend in management literature by paying increasing attention to heterogeneity in CSR actions among family firms (Cruz et al., 2014), the role of female directors in this process has been largely ignored. Second, the presence of the owning family has important implications for board composition (Bammens et al, 2011). While the CSR literature distinguishes between the role of outsiders and insiders in improving the firm CSP, it has not yet considered how family affiliation may influence that relationship for board members in general and female directors in particular (Singh et al., 2015). Our claim is that while female directors will tend to favor family firms' CSP, their ultimate influence will be contingent on whether their appointment is viewed as legitimate and the level of power they hold on the board. We posit that women's insider-outsider character, coupled with their status as a 
family or non-family member, affects their relative legitimacy and power on the board and therefore their ability to push a CSR agenda.

Our analyses of the CSR activities of a sample of publicly held United States family firms over the 2008-2012 period confirm our expectations. Specifically, we observe that it is the presence of women non-family outsider directors and women family insider directors that results in a significant increase in the firm CSP. On the contrary, female directors who are family outsiders or non-family insiders do not seem to influence CSP.

This paper makes several contributions to the literature. First, the article is among the first to consider the role of female directors in the theory of family firms. Women have long been identified as central actors in controlling families (Martinez-Jimenez, 2009) but their influence has tended to be limited to the family sphere (Cesaroni \& Sentuti, 2014). In this sense, our paper contributes to the widely articulated call for incorporating gender considerations as a means of enhancing our understanding of family business dynamics (Martinez-Jimenez, 2009). In so doing, it also contributes to the burgeoning body of literature examining the influence of female directors on the CSR activities of family firms (Rodriguez-Ariza et al., 2017). While extant research analyzes the connection between family ownership and CSR (Cruz et al., 2014), the role played by female directors in fostering CSR activities in family firms has yet to be explored.

Second, our study heeds early calls from corporate governance scholars (e.g. Finkelstein, 1992) to consider the role of power in the association between the board of directors and organizational outcomes. However, these contingent forces have rarely been analyzed. We perform such analysis in the context of family firms and reveal the presence of distinctive board dynamics (i.e. the female director-controlling family relationship) that to date have not been considered in the literature. 
Third, our study highlights heterogeneity among CSP in family firms. Based on the mixed evidence regarding the impact of family ownership on CSR, scholars now caution that comparing family and non-family firms' social orientations may be insufficient to attaining an understanding of how family ownership influences a firm's CSR (Cruz et al., 2014). In line with these arguments, our study acknowledges the important role of family firms' governance mechanisms as a source of such heterogeneity (Chrisman \& Holt, 2016).

\section{THEORETICAL BACKGROUND}

\section{Board of directors, diversity and CSP}

Understanding the organizational factors that predict firms' CSP is a major topic in CSR research (Aguinis and Galvas, 2012). Scholars in this field often highlight the pivotal role played by corporate governance antecedents, and in particular, corporate boards of directors. Certainly, governance drives managers and executives to set goals and objectives pertaining to CSR, and the board is key to meeting and promoting these objectives (Jamali et al., 2008). Accordingly, studies have focused on two overarching characteristics of boards that positively affect a firm's CSP: on the one hand, board structural diversity, such as board size (Bai, 2013), stakeholder representativeness (Hillman et al., 2001) or proportion of outside directors (Hafsi and Turgut, 2013); on the other hand, board demographic diversity, such as experience and community influence (Bai, 2013) and gender board representation (Boulouta, 2013).

While relatively recent, the issue of gender diversity in boardrooms, and its corresponding role in promoting social and environmental issues, has become a major theme of research (Ma, Liang, Yu and Lee, 2012). Through tracing the number and/or percentage of female directors, several studies have associated these indicators with outcomes such as charitable donations (Wang and Cofffe, 1992) and CSR ratings (Krüger, 2009). The 
theoretical logic behind these findings is threefold. First, and in line with the resource dependence theory, women provide different and non-traditional professional experiences and backgrounds (Singh et al., 2008) that enhance decision-making and enable the board to better perform its tasks, including CSR tasks. Second, social role theory suggests that women are socialized to be more "communal" and compassionate than men (Eagly, 2005), and show lower tolerance for ethical compromises (Kennedy and Kray, 2013). As a result, the presence of women on corporate boards generates a more productive discourse (Bilimoria, 2000) and higher sensitivity and attention to the needs of others (Nielsen and Huse, 2010), which enhances CSP. Finally, gender differences in values and management style enhance the monitoring capacity of mixed boards (Adams and Ferreira, 2009), which according to agency theory also reverts positively in CSP. Providing further support to these perspectives, it has been noted that stereotypes regarding women's social inclination are often a major reason for women's nomination at boardrooms (Burges and Tharenou, 2002) and assignment to public affairs committees or CSR areas (Zelechowski et al., 2006).

When examining the impact of female directors on corporate boards, prior research has generally only accounted for the presence and number of women in the boardrooms. The underlying assumption has been that, once appointed as directors women would be accorded the legitimacy and authority that goes with the position. This assumption may not be valid since according to gender studies, power is essential for women to have an impact (Ragins and Sundstrom, 1989). Indeed, research shows that having women on boards may be inconsequential unless they also enjoy the power to influence change (Zelechowski and Bilimoria, 2003). Corporate governance studies also suggest that power, or the ability of individuals to exert their will (Finkelstein, 1992), is contingent on the political context within which boards operate. Neglecting this context is therefore 
problematic, since as noted by Boulouta (2013) the role enacted by board members (and particularly women) will depend on the kind of structural forces and influences that operate on corporate boards.

In this paper, we argue that such forces are particularly salient in the specific case of family firms. This is because the presence of a controlling family, with preferences that extend beyond pure economic outcomes (Gomez-Mejia et al., 2011), provides additional complexity to board dynamics and may alter the basis for power and legitimacy within the board. Therefore, a proper understanding of the role of women directors in CSP in family firms requires a more nuanced theorization of the power and legitimacy of the different women directors. We aim to provide such theorization in the following section.

\section{The different basis of power on family firms' boards}

It is generally recognized that boards of directors in family firms differ from those of nonfamily businesses (Bammens et al., 2011). In an attempt to explain this distinction, authors illustrate two types of motives. First, given the overlapping of ownership and management roles, it is often the case that directors also operate as managers and/or owners of the firm (Anderson and Reeb, 2004). Second, due to the presence of the owning family, which often acts both as the controlling dominant coalition and as a unique stakeholder group of the firm, the board of directors in family firms should reflect a balance between the interests of the family and those of other key stakeholders for the family firm (Bammens et al., 2011). These features of family firms have important implications for board composition, since board membership is negotiated based on the relative power of family owners (Chua, Chrisman, and Sharma, 1999). This negotiation has, in turn, repercussions for directors' legitimacy and power. 
In reviewing the literature on corporate governance in family firms, it is apparent that board members differ along two main dimensions that are particularly relevant when it comes to understanding power and legitimacy. The first is family affiliation. Widely considered a key construct in the family firm literature, manager's family affiliation has been associated with several individual-level variables such as idiosyncratic goals, appointment and remuneration benefits, as well as a unique 'right' to participate in the firm's decision-making processes (Cruz et al., 2010). Indeed, Finkelstein (1992) highlights the importance of family affiliation as an antecedent of power in top management teams. He states that power that stems from the family can be gained either directly by representing shareholders, or indirectly through a director's often long-term interaction with the board, as she translates her unique position into implicit control over board members. Building upon this basis, corporate governance literature has also considered the impact of family affiliation on director's influence (Anderson and Reeb, 2003)

The second relevant dimension to understanding directors' power and legitimacy pertains to the distinction between insider and outsider directors (respectively, employed or not employed by the firm). In the context of CSR, there is a general agreement that the presence of outsider directors would positively influence CSP (Johnson and Greening, 1999). According to agency advocates, outside directors increase the board's monitoring role, reducing managerial discretion to engage in socially irresponsible decisions. It is also argued that outsiders contribute to align managers' interests with long-term goals for shareholders, which may encourage friendly corporate policies towards non-shareholding stakeholders. In addition, resource dependence theory, which highlights a board's resource provision role in the context of CSR, stresses that outsiders often contribute a broader range of experience and knowledge, valuable 
information about other firms' strategies (McDonald and Westphal, 2010), and interactions with external management teams (Mintzberg, 1983). They are also instrumental in accounting for stakeholders' concerns and for reaching out to them (Clarkson, 1995).

Considering these two main dimensions (family affiliation and insider-outsider status), directors in family firms can belong to one of the four following category types: family insider, non-family insider, family outsider and non-family outsider. These classes have distinctive ramifications for directors' abilities to influence board decisions in family firms. Interestingly, only a handful of family business studies explicitly distinguish among directors' typologies (Fiegener et al., 2000), and none of these consider gender diversity. As a result, the role of different types of female directors in influencing family firm outcomes is unknown. This oversight is particularly significant when examining CSR practices, because although the corporate governance literature acknowledges the differential influence of insider and outsider directors in CSP (Johnson and Greening, 1999), it assumes an unequivocal positive relationship in the case of female directors regardless of their role on the board. Furthermore, while family business studies show that family involvement on boards and within top management teams influences CSP in family firms, the literature is silent on the differential impact of types of directors on the social orientation of this firm.

In order to further our understandings of these issues, we argue in the subsequent section that in the case of family firms, the combined effect of female director family affiliation as well their insider/outsider status will determine their relative legitimacy and power to influence board decisions and favor CSR activities. Prior to this, we start establishing as our baseline assumption that the presence of women on the boards of directors of family firms would be correlated with an increase in the firm's CSP. 


\section{HYPOTHESIS DEVELOPMENT}

As noted, existing literature has stressed the positive influence of female directors on a firm's CSP (Boulouta, 2013). Female directors enhance board diversity and, consistent with the propositions of social role theory, tend to exhibit a preference for greater social activity. Studies of gender stereotypes have associated women with altruistic and community-oriented attitudes (e.g. Gilligan, 1982), many of which represent guiding principles related to CSR (Shafer et al., 2007). In the field of management, these qualities have often been used to justify female directors' pro-CSR behavior (e.g. Zhang, Zhu and Ding, 2013). This research suggests that complying with prescriptive gender stereotypes, female directors tend to demonstrate a special sensitivity towards social issues such as CSR (Boulouta, 2013).

We do not expect this general gender-related preference to change with the family affiliation of the director. Indeed, family and non-family female directors should, all things being equal, show a preference for CSR activities. However, it is feasible that not all female directors possess the same power and legitimacy to push a CSR agenda that fits their preferences. In the following section, and based on our typology of female directors, we set a rationale to understand which categories are better able to push the CSR agenda and improve a firm's CSP.

\section{Family ownership and its impact on female directors' power and legitimacy}

According to our previous discussion, and all things being equal, we argue that a female director who is affiliated to the owning family should be more powerful than a manager without such a base of control. When combined with legitimacy considerations, however, the net impact of family affiliation is less straightforward. First, and of particular relevance to the scope of our paper, is the fact that family members are often appointed 
in management positions regardless of their professional qualifications or fitness for the job (Schulze et al., 2001). While this permits preservation of the family's SEW, it also poses legitimacy concerns for the appointed family members vis-à-vis other employees, especially those outside of the family (Gomez-Mejia at al., 2007). This pattern may also exist on boards. For example, recent investigations of top French companies emphasize the link between the proportion of women on French corporate boards and family affiliation (Singh et al., 2015). In the absence of unique personal assets to justify their appointment on the board, female directors with strong ties to owning/founding families might be deemed token women. In other words, women appointed to corporate boards who are perceived as symbolic members or mere family representatives run the risk of having their legitimacy as directors questioned. Hence, while the preference for these women might be better aligned with the alternative of greater CSR, we argue that they will not be sufficiently influential to move the whole board towards that end.

This is not the case for family directors who are also insiders. Contrary to female family directors who are outsiders, those who are insiders enjoy a natural legitimacy since their skills are certified by the functional role they hold within the firm and their deep knowledge of the company's inner functioning. This enables them to undertake their board work without criticism that they are only there because they are affiliated to the family. Holding a formal organizational position also accords female directors structural power. As expressed by Finkelstein (1992: 509): “Managers who have a legislative right to exert influence are influential."

In sum, we posit that by combining the power and legitimacy that stems from their dual standing as family owners and firm managers, female directors who are family insiders will exhibit a certain influence on board members. As such, they will be able to enact their gender role and push the board's CSR agenda. It follows that a family firm with a 
high proportion of female directors who can be classified within this category should demonstrate a comparatively higher CSP. Formally stated:

Hypothesis 1 'The higher the percentage of family female directors who are insiders, the higher the family firm's CSP.'

\section{Non-family female directors and the importance of independence}

Although family directors may represent a sizable proportion of women on a family firm's board, the majority of women in listed family firms tend to be unaffiliated to ownership (Singh et al., 2015). Non-family insiders and non-family outsiders fall into this broad category. Could these female directors enjoy any influence in the absence of ownership power? We now posit that this is possible in the case of non-family outsider women.

We first draw on the literature concerning top management team power (Finkelstein, 1992), which establishes that in addition to structural and ownership power, top managers can derive power from two other sources: expertise and prestige. Expert power stems from knowledge of how to perform the diverse tasks that may be essential for the organization. Prestige power emanates from personal prestige or status. As experts in their particular domain, and as sources of external prestige and reputation for the family firm, the views of a female director who is an outsider are perceived as more legitimate, and her voice becomes that of an influential director, rather than of a representative of a particular demographic group, i.e. women.

In addition, the resource-dependence approach distinguishes between the types of resources brought to the board by insider and outsider directors (e.g. Baysinger and Hoskisson, 1990). While insider directors may have greater incentives to provide resources to the firm, outsiders are valued for their experience and ability to make important decisions (Hillman and Dalziel, 2003). Because of their wider diversity of 
backgrounds, outsider board members are more likely than insider directors to define organizational performance beyond financial terms (Zahra et al., 1993), placing them closer to the objectives of CSR. Consistent with this perspective is the fact that the evidence indicates that outsider board members will exhibit greater concern for society's demands (Ibrahim and Angelidis, 1995) and that the percentage of outside directors is positively associated with high corporate social responsibility (Zahra et al., 1993; Zhang et al, 2013).

Also, the corporate governance literature has used agency arguments to claim that outsider directors hold more power and are better positioned to defend their own views and preferences even against CEOs or owners who hold opposite views in firm affairs. (Baysinger and Hossikison, 1990). This is particularly important when it comes to CSR in family firms. As shown by previous literature (Rodriguez-Ariza et al., 2017) controlling families in family firms may be reluctant to pursue a pro-social agenda, particularly in the internal dimensions of CSR. Furthermore, as managers of the family firm, non-family insider directors face greater risks and accountability for the firm's performance (Gomez-Mejia et al., 2003), which may make them less prone to engage in CSR activities with uncertain economic results, at least in the short term (Cruz et al., 2014).

Hence, according to these arguments, outsider directors hold more power than insiders and are in a superior position to protect the interests of executives and non-shareholding stakeholders. In this sense, non-family female directors who are outsiders will gain some measure of influence over board members and are therefore better placed to enact their role as proponents and defenders of a more active CSR agenda. Thus, we expect that the more non-family female outsider directors who operate on the board, the greater the commitment of family firms with CSR. Formally: 
Hypothesis 2 'The higher the percentage of non-family female directors who are outsiders, the higher the family firm's CSP.'

\section{METHODS}

\section{Sample and Data Collection}

We used the list of publicly-held companies in the United States of America that belong to the Fortune 1000 during the period 2008-2012, excluding those for which information was unavailable in the Compustat database. Following studies on the performance of listed firms in general (Fama and French, 1992) and family firms in particular (i.e. Villalonga and Amit, 2006), we excluded companies from the financial and government sector. This resulted in 616 firm observations. We used Compustat Global as our principal source to obtain firm financial information, sector of activity, size and age. Information about the presence of independent directors in the board was garnered from the Thompson Reuters database.

We manually inspected each firm's proxy statement to determine whether or not it classified itself as a family firm, as well as the influence of family members in firm governance. In some cases, the proxy statement provided explicit information about family ownership. Yet for most observations, family ownership was determined as the sum of the percentage of shares owned by each individual of the controlling family group, either directly or indirectly (most likely through a family trust). In order to identify family relationships, we looked for accordance in surnames and also used a number of keywords to identify kinship ties between individuals (e.g. father, mother, son, daughter, cousin). We adopted the same search strategy to determine the presence of family members on the board of directors of family firms, including family female directors. 
Following standard criteria used in previous studies on publicly traded American family companies (Gomez-Mejia et al., 2003, Villalonga and Amit, 2006; Berrone et al, 2010), we classified the company as a family firm if two criteria were met: a) an individual or a family group owned at least $5 \%$ of the shares during the whole period, ${ }^{1}$ and $b$ ) at least one member of the owning family was on the board of directors. The 5 percent cut-off is comparable to prior studies that use this convention for large publicly traded American firms, both in the corporate governance literature in general (see review by Tosi et al, 1999) and in family firm studies (Villalonga \& Amit, 2006; Miller et al., 2007). Adding the criteria of identifying at least one family member in the board results in a more conservative definition of family firm, but it ensures that the family influences firm strategic decision making (Gomez-Mejia et al, 2003).

Following this process, our final panel consisted of 152 American listed family firms (758 firm year observations). The manual inspection of proxy statements of each company, also allowed us to review information about the board of directors and classify female directors according to their role on the board.

CSP has been collected by the CSRHub database, the world's largest CSR database, which provides social, environmental, community, and governance ratings on approximately 7,000 companies from 135 industries in 91 countries. It is also the first database that combines data from five of the leading socially responsible investment (SRI) analysis firms (also known as Environment, Governance-ESG), and over 120 influential non-governmental organizations (NGOs). Thus, the data are relatively objective, not based solely on self-reported measures and less likely to suffer from social desirability biases. CSRHub has recently been utilized in the context of social

\footnotetext{
${ }^{1}$ In line with Villalonga \& Amit (2006), we regarded the focal family as the one whose members possessed the highest percentage of shares.
} 
responsibility, both in academic (Bu, Wagner, and $\mathrm{Yu}, 2013$; Cruz et al., 2014) and practitioner environments (Gidawani, 2013). ${ }^{2}$

We collected data regarding CSP from 2009 until 2013. In order to guarantee time causality, ownership and financial information for a given year were matched with the CSRHub rates of the subsequent year. For example, financial and ownership information for 2008 were matched with CSRHub rates for 2009. We ended up with five blocks of matched data that constituted a balanced 5-year panel (760 observations).

\section{Variable measurement}

Dependent variable: Corporate social performance (CSP)

While a variety of measurements approaches have been utilized to assess CSR actions, in this paper we follow an "objective approach" (Morgeson et al., 2013) and rely on the firms's sustainability ratings released by CSRHub to proxy for firms' CSP.

CSRHub is an independent organization (www.csrhub.org) that provides information on social performance in over 7,000 companies from 135 industries in 91 countries. The CSRHub methodology maps each element of data it receives from a data source into one or more subcategories and converts it to a numeric scale from 0 to $100(100=$ positive rating). Subsequently, it compares the scores from different data sources for the same company and adjusts all the scores from a source to remove bias and create a more consistent rating. It finally aggregates these ratings to category level. Four main categories became apparent: two related to internal stakeholders (employees and governance), and two related to external stakeholders (the environment and community). Closer inspection of the governance category shows that CSRHub uses the percentage of female directors as one of its metrics to compute the governance score and its inclusion

\footnotetext{
${ }^{2}$ We provide more information about CSRHub rates in the subsection describing the dependent variable of the study.
} 
as an outcome variable would be likely to produce spurious correlations. Therefore, we limited our focus to the employees' category as our measure for CSP towards internal stakeholders. We also decided to focus on the 'community' dimension in order to capture CSP with external stakeholders, since previous research suggests that as environmental sustainability becomes mainstream, pro-environment attitudes are becoming more gender-neutral (Hechevarría et al., 2016). We calculated the total CSR performance for each company as the sum of the firm's score in each of the two aforementioned dimensions (community and employees). ${ }^{3}$

\section{Independent variables:}

Women on the board. We defined the influence of female directors in terms of the percentage of women represented on the board in relation to the board size (Boulouta, 2013; Amore et al., 2014).

Women's roles on the board. We classified female directors as insiders if they were also officers of the firm, and as outsiders if they were non-management board members (Daily et al., 1999). Furthermore, we defined them as family directors if they belonged to the owning family by using the aforementioned criteria (i.e. coincidence in the individual surnames and keywords to identify kinship ties between individuals). In combining the two criteria, we distinguished four types of female directors: a) Family insiders are family female directors who are also officers in the firm; b) Non-family insiders are women who do not have family ties with the owning family but belong to the executive team of the family firm; c) Family outsiders are female board members with family ties but with no

\footnotetext{
${ }^{3}$ The employees category includes disclosure of policies, programs, and performance in diversity, labor relations and labor rights, compensation, benefits (including those that engage employees and improve worker development), and employee training, health and safety. The community category covers the company's commitment to its local, national and global community. It reflects a company's citizenship, charitable-giving programs, and volunteerism. It also covers a company's responsibility for the development, design, and management of its products and services, and their impacts on customers and society at large. It also relates to product safety, quality, and the company's response to problems with safety and quality.
} 
executive role in the firm, and d) Non-family outsiders, are female directors who are not part of the family and who do not have an executive role in the firm. For each company, we aggregated the number of women in each role and computed the percentage of women in each category by dividing this number by the size of the board.

\section{Control variables}

We included several control variables to control for other potential determinants of a company's CSR. We first controlled for firm size, measured a firm's total assets, since larger firms are subjected to closer public scrutiny from media, special interests, and stakeholders than smaller ones, thereby raising the likelihood of them acting in more socially responsible ways (Fombrun \& Shanley, 1990). In order to correct for skewness in multivariate analyses, we included the logarithm transformation of these total assets. We also controlled for firm age in terms of the number of years since the firm's creation and used its logarithm transformation in the multivariate analysis. Finally, we also controlled by past firm performance measured in terms of the firm's ROA.

We used a continuous family ownership variable to account for the influence of family owners in each company. This variable was defined as the voting power of the focal family in each of the sampled years. We also controlled for several variables regarding the composition of the board, including the percentage of family directors and the percentage of independent directors as related to board size. Finally, we included female directors' age and tenure on the board, which may influence their CSR performance. In order to ensure consistency with the other analyses (firm level), individual board members' information was aggregated to compute the average per firm.

\section{Estimation methods}


Firm-specific unobserved variables, i.e. unobserved variables that represent timeinvariant properties of firms (such as managerial ability, or the political context in which a firm operates), may affect CSR but are difficult to observe or measure. Traditional panel data analysis (such as fixed-effects analysis) might account for such endogeneity under certain assumptions (Wooldridge, 2002). However, we could not control for firm fixed effects because the extent of family control and the presence of female directors had very little variation during the sample period. Accordingly, we ran panel data with random effects. Significance tests were computed with robust standard errors clustered by firm to account for non-independence of observations and heteroskedasticity.

\section{RESULTS}

The descriptive statistics are reported in Table 1. In relation to the board composition, Table 1 shows that the majority of the board members in listed family firms (75\%) are independent directors, with family directors representing about $20 \%$ of the board members. In line with previous studies (Adams and Ferreira, 2009; Amore et al., 2014), women are underrepresented on the boards, with only $13 \%$ of the total board members being female. Following our typology, most of these women are family outsiders, accounting for $11 \%$ of the total board members. The analyses of correlations show that the percentage of woman on a board is positively correlated with CSP. Yet, in line with our predictions, the signs and significance of the correlation coefficients change when we consider the different roles of the female directors.

Insert Table 1 about here

Tables 2 and 3 summarize the results of the panel data models to determine the effect of female directors and their different respective categories on CSP. In line with our baseline assumption, and consistent with previous literature, the influence of female directors in 
enhancing CSP is confirmed in the case of family firms. Interestingly, Table 2 shows that neither non-family insiders nor family outsiders' directors influence CSP in family firms.

\section{Insert Table 2 about here}

In Table 3, we break down the percentage of female directors based on our proposed typology (namely family insider, family outsider, non-family insider and non-family outsider). As we hypothesized, the impact of female directors on CSP in family firms transcends their gender role. Model 1 shows that in the case of women family directors, only those who are also officers in the firm (family insiders) have a (positive) influence on the firm's CSP, thus supporting Hypothesis 1. In contrast, in the case of non-family female directors, the positive impact on CSP comes from those who do not possess an executive position in the firm (non-family outsiders), providing support to Hypothesis 2.

Insert Table 3 about here

\section{Post hoc analyses}

We first distinguish between internal (employees) and external (community) dimensions of CSP. Although our theorizing does not foresee a differential impact of our independent variables on each social dimension, we acknowledge that they each have unique attributes and are therefore worthy of independent scrutiny (Cruz et al, 2014; Wang et al., 2016). The results in Table 1 show a strong correlation between the two different dimensions of CSP, but also a high standard deviation, indicating that there are significant differences within companies in their CSP regarding internal and external stakeholders. As can be seen in Table 2, the influence of female directors is significant for both the employees and the community dimensions of CSP. When different types of women directors are considered (see Models 2 and 3 in Table 3) we still observe the positive influence of family insider and non-family outside directors we previously reported for total CSP. 
These results further confirm hypotheses 1 and 2. Yet, contrary to our expectations, female family outsider directors also have a positive effect on the employee dimension of CSR. Furthermore, the results confirm the negative effect of family ownership on the internal CSP in the case of family firms (Cruz et al., 2014).

We performed some other additional analyses in order to test the robustness of our results. First, we were concerned with the small percentage that all the family female typologies represent over the total board size, with the exception of the family outsider category. In the absence of multicollinearity problems, this small percentage may explain the large beta coefficient that we obtained in some of the regressions. A closer look reveals that although there was more than one non-family outsider director in $32 \%$ of the firms, this percentage falls to $4 \%$ in the case of family outsiders, and to $0.6 \%$ for family insiders. This indicates that the variable that renders family firms different in terms of their boards' gender composition is the presence of at least one female director.

Consequently, we replicated the analyses for Hypotheses 1 and 2 by using a dummy variable that takes the value of " 1 " if there is "at least one female director of each type" (“0”). The results displayed in Table 4 offer further support to both Hypotheses. The presence of at least one family insider woman director is enough to positively influence a firm's CSP regarding both dimensions. Also consistent with our expectations, the presence of at least one non-family outsider female director positively affects family firm CSP, hence these women's place on the board is legitimized and they hold significant power over decision-making. In contrast, and as illustrated in the previous analyses, the presence of "at least one non-family insider" and of "at least one family outsider" do not play any role in determining the CSP of their firms.

Insert Table 4 about here 
The above analyses support our arguments that understanding differences in legitimacy and power among the different types of female directors is key to explaining the heterogeneity among CSP in family firms. Nevertheless, the observed differences could also be due to other factors that distinguish the four categories of women, and which may be unrelated to their power and legitimacy in the company. To dismiss alternative explanations, we performed additional exploratory analyses at the individual (female directors') level, as opposed to our previous unit of analysis (the firm level).

First, we analyzed whether there were age differences between women in the four groups, since previous research has indicated a generational gap in directors to explain why female directors positively impact CSP (Terjesen et al., 2009). Our analyses show that this is not the case in our sample, since there are no significant age differences among the four categories of female directors. Second, we investigated if these women differed in their "CSR background," i.e. in whether they had previous experience in dealing with CSR aspects. In order to do so, we manually inspected the biographies of the female directors as shown in the firms' proxy statements. We concluded that a woman had a CSR background if she had been involved in philanthropic activities, foundations or NGOs. The differences among the four categories of female directors in relation to their CSR background were statistically significant $(\mathrm{p}<0.01)$. The proportion of female directors with CSR backgrounds was higher among non-family outsiders (58\%), while that of family insiders with a CSR background was much lower (27\%). Hence in the case of these women, their inclination towards CSR does not seem to be driven by their involvement in CSR activities outside of the family firm. 


\section{DISCUSSION}

We have corroborated the premise that female directors are central to understanding heterogeneity in family firms' CSP. More importantly, our analyses confirm that female directors have widely varying levels of influence on the CSP of family firms. Therefore, it seems incorrect to talk about the effect of women per se, at least in the case of family firms. Rather, accounting for female directors' power and legitimacy on boards seems warranted in order to make accurate predictions about their actual influence over firms' strategic decisions.

When the generic effect of women is considered it is unsurprising to find a significant (and positive) effect of the proportion of female directors on CSP. Yet, an assessment of the impact of the presence of women in the boardroom on CSP in family firms needs to acknowledge the relative presence of each category of female directors. Of particular importance is the balance between women non-family outsiders and family insiders. Our results show that both types of female directors "make a better table," i.e. greater representation of both types enhances CSP in family firms.

In the case of female non-family outsiders, our findings accord with previous studies in non-family contexts that show that female outsider directors are encouraged to support CSP (as per their gender role), and have the discretion to do so (as per their role as outsiders). The fact that these levels of motivation and discretion do not change with the presence of a controlling owner with strong monitoring capacity (including the ability to select and dismiss board members) and distinct family goals (some of which are contrary to fostering CSP) is interesting. It would appear that family owners value the expertise brought by these non-family outsiders, who are empowered to make their voices heard in the boardroom even when it contradicts the interests of the family. A different picture emerges in the case of family female outsider directors, whose influence on CSP is 
restricted to the employee dimension. To exert an influence, family female outsider directors also need to reach a relatively higher numerical representation on the board. A possible explanation for this non-significant result is that family women who do not work in the company but occupy board seats are considered token women, with low levels of legitimacy and power to affect board decisions. Their directorship may be another sign of the family control of the company, and a possible mechanism to reinforce it.

The fact that both family insider and outsider directors enhance the employee dimension of CSP suggests that women family directors "humanize the workplace" (Edlund, 1992) in their firms. This positive effect is even more striking given the negative impact that (according to our results) both family ownership and the presence of family directors have on this particular CSP internal dimension. Family female directors might indeed stick to their feminine values when faced with employee-related issues, despite their otherwise unwavering commitment to the family's SEW. Having family women in strategic managerial positions signals companies' commitment to the advancement of gender diversity (Burke, 1994). Family female directors are more likely to consider their responsibility to address during board meetings issues of gender diversity regarding employee recruitment, retention, development, and advancement in organizations, and thus act as modest forces for change, with effects on morale as well as the retention of managerial women (Burke, 1994). These findings are interesting since most of the scant literature on the subject tends to describe women as "fiercely loyal to the family business" (Salganicoff, 1990), as their legitimacy within the business is predominantly tied to their family role (Martinez-Jimenez, 2009). Given the negative impact of family ownership on the employee dimension of CSR, our results suggest that the gender role is more salient in terms of decisions regarding the CSP of the firm. 
This analysis of insider female directors also offers interesting insights to both the corporate governance and the family business literature. Very few women hold positions in both the executive suite and the corporate boardroom, and family firms do not seem to be an exception. However, our results clearly show that the ability of these insider women to influence CSP is highly dependent on their family ties.

Although we did not formulate an explicit hypothesis, since doing so would imply to test for a null effect, our results also show that non-family insider female directors do not play any role in influencing CSP. These female directors face a dilemma between their gender role to support CSR and their position as directors of the family firm. The economic impact of CSP is uncertain at best, and according to our results and in line with previous research (Cruz et al., 2014), family owners may not necessarily be enthusiastic about CSP, especially as regards internal stakeholders. Therefore, to reduce their risk of redundancy, non-family insiders may avoid advocating for CSP in the boardroom. These women may not only lack motivation to support CSP, but also the discretion to do so. This is because family owners are reluctant to empower key executives, to prevent losing SEW benefits related to maintaining family control (Cruz et al, 2010).

\section{Future research}

In this paper we have relied upon corporate governance and family literature to draw inferences about the extent to which females hold power and are considered legitimate in the boardroom. Future research might benefit from measuring women's actual power by examining, for example, their presence on important committees such as nomination and remuneration. This line of research would extend early surveys of women's presence on such committees (Bilimoria \& Piderit, 1994).

Researchers should continue to investigate other factors that may accordingly moderate the relationship between female directors and the family firm's CSR. For example, the 
relationship between female board representation and social behaviors may be more positive for family firms that operate in controversial industries. Berrone et al. (2010) suggest that in polluting industries, families may be more concerned about their image and reputation and consider CSR a critical component of their firm's strategy. As such, board members might be more sensitive to female directors' pro-social views. In particular, female directors with CSR-related expertise might acquire greater expert power. As expressed by Finkelstein (1992: 509), expert "power tends to accrue best when a manager's expertise is in an area critical to an organization. Enhanced power may in turn strengthen the influence of women's directors on a family firm's CSP.

Similarly, in searching for indicators of female directors' legitimacy and power, we considered personal characteristics such as family ties or of being an outsider. Further research examining the other factors that may determine whether and how female directors influence social performance, especially those that affect the heterogeneity of family firms, is required.

Although this paper has focused on the influence of female directors on one particular aspect where gender makes a difference - CSR - future research could also extend inquiry to their impacts on other strategic outcomes. In particular, and given scholars' interest in family firms' entrepreneurial behavior (e.g. Zellweger, Nason and Nordqvist, 2012), the gendered nature of entrepreneurship in general and in family firms in particular (Cruz, Justo and De Castro, 2012), research could benefit from investigating female directors' impacts on the entrepreneurial activity of these firms. 


\section{REFERENCES}

Adams, R.B. \& Ferreira, D. (2009). Women in the boardroom and their impact on governance and performance. Journal of Financial Economics, 94, 291-309.

Aguinis, H. \& Glavas, A. (2012). What we know and don't know about corporate social responsibility a review and research agenda. Journal of management, 38(4), 932968.

Amore, M.D., Garofalo, O. \& Minichilli, A. (2014). Gender interactions within the family firm. Management Science, 60(5), 1083-1097.

Anderson, C. R., \& Reeb, M. D. (2003). Founding-family ownership and firm performance: Evidence from the S\&P500. The Journal of Finance, LVIII (3), 1301-1328.

Anderson, C. R., \& Reeb, M. D. (2004). Board composition: Balancing family influence in S\&P 500 firms. Administrative Science Quarterly, 49, 209-237.

Bai, G. (2013). How do board size and occupational background of directors influence social performance in for-profit and non-profit organizations? Evidence from California hospitals. Journal of Business Ethics, 118, 171-187.

Bammens, Y., Voordeckers, W. \& Van Gils, A., (2011). Boards of Directors in Family Businesses: A Literature Review and Research Agenda. International Journal of Management Reviews, 13(2), 134-152.

Baysinger, B \& Hoskisson, R.E. (1990). The Composition of Boards of Directors and Strategic Control: Effects on Corporate Strategy. Academy of Management Review, 15, 72-87.

Berrone, P., Cruz, C., Gomez-Mejia, L. \& Larraza-Kintana, M., (2010). Socioemotional wealth and corporate responses to institutional pressures: Do family-controlled firms pollute less? Administrative Science Quarterly, 55, 82-113.

Bilimoria, D. (2000). Building the business case for women corporate directors. In R. J. Burke \& M. C. Mattis (Eds.), Women on corporate boards of directors: International challenges and opportunities: 25-40. Dordrecht: Kluwer Academic Publishers.

Bilimoria, D., \& Piderit, S. K. (1994). Board committee membership: Effects of sexbased bias. Academy of Management Journal, 37, 1453-1477.

Boulouta, I. (2013). Hidden Connections: The link between board gender diversity and corporate social performance. Journal of Business Ethics, 113, 185-197.

$\mathrm{Bu}$, Liu, Wagner, and Yu (2013). Corporate social responsibility and the pollution haven hypothesis: evidence from multinationals' investment decision in China. Asia-Pacific Journal of Accounting \& Economics, 20(1), 85-99.

Burges, Z., \& Tharenou, P. (2002). Women board directors: Characteristics of the few. Journal of Business Ethics, 37(1), 39-4.

Burke, R. (1994). Women on corporate boards of directors: views of Canadian chief executive officers. Women in Management Review, 9(5), 3-10.

Cesaroni, F. M., \& Sentuti, A. (2014). Women and family businesses. When women are left only minor roles. The History of the Family, 19(3), 358-379.

Chua, J. H., Chrisman, J. J., \& Sharma, P. (1999). Defining the family business by behavior. Entrepreneurship Theory and Practice, 23(4), 19-39.

Chrisman, J.J. \& Holt, D.T. (2016). Beyond socioemotional wealth: taking another step toward a theory of the family firm. Management Research, 14, 279-287.

Clarkson, M. B. E. (1995). A Stakeholder Framework for Analyzing and Evaluating Corporate Social Performance. The Academy of Management Review, 20(1), 92-117.

Cruz, C., Gomez-Mejia, L.R., \& Becerra, M. (2010). Perceptions of benevolence and the design of agency contracts: CEO-TMT relationships in family firms. Academy of Management Journal, 53, 69-89. 
Cruz, C., Larraza-Kintana, M., Garcés-Galdeano, L. \& Berrone, P. (2014). Are family firms really more socially responsable? Entrepreneurship Theory and Practice, 38 (6), 1295-1316.

Cruz, C., Justo, R., \& De Castro, J.O. (2012). Does family employment enhance SMEs performance? Integrating socioemotional wealth and family embeddedness perspectives. Journal of Business Venturing, 27(1), 62-76.

Daily, C. M., Certo, S. T. \& Dalton, D. R. (1999). A decade of corporate women: Some progress in the boardroom, none in the executive suite. Strategic Management Journal 20, 93-99.

Eagly, A. H. (2005). Achieving relational authenticity in leadership: does gender matter? Leadership Quarterly, 3, 459-474.

Edlund, C. J. (1992). Humanizing the workplace: Incorporating feminine leadership. Public Management in an Interconnected World, 75-88.

Elstad, B., \& Ladegard, G. (2012). Women on corporate boards: key influencers or tokens? Journal of Management \& Governance, 16(4), 595-615.

European Commission (2010). Women on boards: Commission proposes $40 \%$ objective. Retrieved from http://ec.europa.eu/justice/newsroom/genderequality/news/121114_en.htm.

Fama, E. \& French, K.R. (1992). The Cross-Section of Expected Stock Returns. The Journal of Finance, 47, 427-465.

Fiegener, M.K, Bonnie M B., Dirk R D, \& William J D. (2000). CEO Stakes and Board Composition in Small Private Firms. Entrepreneurship Theory and Practice, 24, 5-24.

Finkelstein, S. (1992). Power in top management teams: dimensions, measurement and validation. Academy of Management Journal, 35, 505-538.

Fombrun, C. J., \& Shanley, M. (1990). What's in a name? Reputation building and corporate strategy. Academy of Management Journal, 33, 233-258.

Gidawani, B. (2013). The link between brand value and sustainability, The Conference Board. October, Report DN-V5N21-13 (http://www.conferenceboard.org/publications/publicationdetail.cfm?publicationid=263 1)

Gilligan, C. (1982). In a different voice: Psychological theory and women's development. Cambridge, MA: Harvard University Press.

Gomez-Mejia, L.R., Larraza-Kintana, M. \& Makri, M. (2003). The determinants of executive compensation in family-controlled public corporations. Academy of Management Journal, 46, 226-237.

Gomez-Mejia, L. R., Haynes, K., Nuñez-Nickel, M., Jacobson, K., \& Moyano-Fuentes, J. (2007). Socioemotional wealth and business risks in family controlled firms: evidence from Spanish olive oil mills. Administrative Science Quarterly, 52, 106-137.

Gomez-Mejia, L. R., Cruz, C., Berrone, P., \& De Castro, J. (2011). The bind that ties: socioemotional wealth preservation in family firms. The Academy of Management Annals, 5, 653-707.

Hafsi, T., \& Turgut, G. (2013). Boardroom diversity and its effect on social performance: Conceptualization and empirical evidence. Journal of Business Ethics, 112, 463-479.

Hechevarría D., Terjesen S., Ingram A., Renko M., Justo R., \& Elam A. (2016). Taking Care of Business: The Impact of Culture and Gender on Entrepreneurs' Blended Value Creation Goals. Small Business Economics, 1-33.

Hillman, A.J. \& Dalziel, T. (2003). Boards of Directors and Firm Performance: Integrating Agency and Resource Dependence Perspectives. The Academy of Management Review, 28(3), 383-396. 
Hillman, A. J., Keim, G. D., \& Luce, R. A. (2001). Board composition and stakeholder performance: Do stakeholder directors make a difference? Business and Society, 40, 295314.

Ibrahim, N. A., \& Angelidis, J. P. (1995). The corporate social responsiveness orientation of Board members: Are there differences between inside and outside directors? Journal of Business Ethics, 14(5), 405-410.

Jamali, D., Safieddine, A. M. \& Rabbath, M. (2008). Corporate Governance and Corporate Social Responsibility Synergies and Interrelationships. Corporate Governance: An International Review, 16, 443-459.

Johnson R. A. \& Greening D.W. (1999). The Effects of Corporate Governance and Institutional Ownership Types on Corporate Social Performance. The Academy of Management Journal, 42(5), 564-576.

Kennedy, J. A., \& Kray, L. J. (2013). Who is willing to sacrifice ethical values for money and social status? Gender differences in reactions to ethical compromises. Social Psychological and Personality Science, 5, 52-59.

Krüger, P. (2009). Corporate social responsibility and the board of directors. Job Market Paper. Toulouse School of Economics, France.

Ma, Z., Liang, D., Yu, K. H., \& Lee, Y. (2012). Most cited business ethics publications: mapping the intellectual structure of business ethics studies in 2001-2008. Business Ethics: A European Review, 21(3), 286-297.

Martinez-Jimenez, R. (2009). Research on women in family firms: Current status and future directions. Family Business Review, 22(1), 53-64.

Mcdonald M.L. \& Westphal J.D. (2010). Control, CEO identification with the corporate elite, and strategic help provided to CEOs at other firms. The Academy of Management Journal, 53(2), 343-370.

Miller, D., Le Breton-Miller, I. Lester, R. H. \& Cannella, A.A. (2007). Are family firms really superior performers? Journal of Corporate Finance, 13(5), 829-858

Mintzberg, (1983). Power in and around organizations. Englewood cliffs NJ: Prentice Hall.

Morgeson, F. P., Aguinis, H., Waldman, D. A., \& Siegel, D. S. (2013). Extending corporate social responsibility research to the human resource management and organizational behavior domains: A look to the future. Personnel Psychology, 66(4), 805824.

Nielsen, S. \& Huse, M. (2010a). The contribution of women on boards of directors: going beyond the surface. Corporate Governance: An International Review, 18, 136-148.

Peloza, J. (2009). The challenge of measuring financial impacts from investments in corporate social performance. Journal of Management, 35(6), 1518-1541.

Ragins, B. R. \& Sundstrom, E. (1989). Gender and Power in Organizations: A Longitudinal Perspective. Psychological Bulletin, 105(1), 51-88.

Rao, K. \& Tilt, C., (2016). Board Composition and Corporate Social Responsibility: The Role of Diversity, Gender, Strategy and Decision Making, Journal of Business Ethics, 138(2), 327-347.

Rodriguez-Ariza, L., Cuadrado-Ballesteros, B., Martinez-Ferrero, J. \& Garcia-Sanchez, M.I. (2017). The role of female directors in promoting CSR practices: An international comparison between family and non-family businesses. Business Ethics; A European Review, 26, 162-174.

Rowley, T. \& Berman, S. (2000). A brand new brand of corporate social performance. Business \& Society, 39(4), 397-418.

Salganicoff, M. (1990). Women in family businesses: Challenges and opportunities. Family Business Review, 3(2), 125-137. 
Shafer, W.E., Fukukawa, K., \& Lee, G. M. (2007). Values and the perceived importance of ethics and social responsibility: The U.S. versus China. Journal of Business Ethics, 70, 256-284.

Schulze, W. S., Lubakin, L.H., Dino, R.N. \& Buchholtz, A.K. (2001). Agency Relationships in Family Firms: Theory and Evidence. Organization Science, 99-116.

Singh, V., Point, S., Moulin, Y., \& Davila, A. (2015). Legitimacy profiles of women directors on top French company boards. Journal of Management Development, 34(7), 803-820.

Singh, V., Terjesen, S. \& Vinnicombe, V. (2008). Newly appointed directors in the boardroom: How do women and men differ? European Management Journal, 26(1), 4858 .

Short, J.C., Moss, T.W. \& Lumpkin, G.T., (2009). Research in social entrepreneurship: Past contributions and future opportunities. Strategic Entrepreneurship Journal, 3(2), 161-194.

Terjesen, S., Sealy, R. \& Singh, V. (2009). Women directors on corporate boards: a review and research agenda. Corporate Governance: An International Review, 17, 320337.

Terjesen, S. \& Sealy, R. (2016). Board gender quotas: Exploring ethical tensions from a multi-theoretical perspective. Business Ethics Quarterly, 26(1), 23-65.

Tosi, H.L., Gomez-Mejia, L.R., Loughry, M.L., Werner, S., Banning, K., Katz, J., Harris, R., \& Silva, P. (1999). Ownership distribution and managerial discretion. In G. Ferris (Ed.), Research in Personnel and Human Resources Management, 7. Greenwich, CT: JAI Press.

Villalonga, B., \& Amit, R. (2006). How do family ownership, control and management affect firm value? Journal of Financial Economics, 80, 385-417.

Wang, H., Tong, L., Takeuchi, R., George, G. (2016). Corporate Social Responsibility: an overview and new research directions. Academy of Management Journal, 59(2), 534544.

Wang, J. \& Coffee, B.S. (1992) Board Composition and Corporate Philanthropy. Journal of Business Ethics, 11, 771-778.

Wooldridge, J. (2002). Econometric Analysis of Cross Section and Panel Data, MIT Press.

Zahra, S. (1993). Conceptual model of entrepreneurship as firm behavior: A critique and extension. Entrepreneurship Theory and Practice, 14(4), 5-21.

Zellweger, T. M., Nason, R. S., \& Nordqvist, M. (2012). From longevity of firms to transgenerational entrepreneurship of families: Introducing family entrepreneurial orientation. Family Business Review, 25(2), 136-155.

Zelechowski, D.D. \& Bilimoria, D. (2003). The Experience of Women Corporate Inside Directors on the Boards of Fortune 1000 Firms. Women In Management Review, 18(7), 376-381.

Zelechowski, D.D., Bilimoria, D. \& Haug, Ralph (2006). Female Directors, CEO Characteristics, and Board Structure, Journal of Academy of Business and Economics, 6(1), 189-196.

Zhang, J. Q., Zhu, H., \& Ding, H. (2013). Board composition and corporate social responsibility: An empirical investigation in the post Sarbanes-Oxley era. Journal of Business Ethics, 114, 381-392. 
Table 1: Mean, standard deviations, and zero-order correlations.

\begin{tabular}{|c|c|c|c|c|c|c|c|c|c|c|c|c|c|c|}
\hline Variable & Mean & S. D. & 1 & & 2 & & 3 & & 4 & & 5 & & 6 & \\
\hline 1. Community & 48.657 & 10.175 & 1 & & & & & & & & & & & \\
\hline 2. Employee & 50.365 & 9.701 & 0.549 & $* * *$ & 1 & & & & & & & & & \\
\hline 3. CSR & 50.246 & 7.977 & 0.877 & $* * *$ & 0.8634 & $* * *$ & 1 & & & & & & & \\
\hline 4. Family onwership & 0.359 & 0.268 & -0.070 & + & -0.142 & $* * *$ & -0.127 & $* * *$ & 1 & & & & & \\
\hline 5. Ins. investors & 0.188 & 0.130 & -0.107 & $* *$ & -0.171 & $* * *$ & -0.269 & $* *$ & 0.019 & & 1 & & & \\
\hline 6. Firm size & 8.393 & 1.354 & 0.031 & & 0.188 & $* *$ & 0.125 & $* *$ & -0.069 & + & -0.266 & $* * *$ & 1 & \\
\hline 7. ROA & 0.095 & 0.074 & 0.167 & $* * *$ & 0.210 & $* * *$ & 0.279 & $* * *$ & -0.082 & + & -0.243 & $* * *$ & 0.115 & $* *$ \\
\hline 8. Firm age & 40.629 & 30.180 & -0.038 & & 0.071 & + & -0.004 & & 0.032 & & 0.027 & & 0.008 & \\
\hline 9. Age Women & 40.629 & 30.180 & 0.023 & & 0.005 & & -0.024 & & 0.015 & & 0.020 & & -0.025 & \\
\hline 10. Tenure Women & 57.313 & 6.876 & 0.038 & & -0.017 & & -0.061 & & -0.016 & & -0.054 & & 0.095 & $*$ \\
\hline 11. Indepen. board & 0.748 & 0.116 & 0.015 & & 0.098 & $* *$ & 0.083 & $* * *$ & -0.290 & $* * *$ & 0.151 & $* * *$ & -0.008 & \\
\hline 12. Family board & 0.198 & 0.111 & -0.065 & + & -0.125 & $* * *$ & -0.179 & $* * *$ & 0.329 & $* * *$ & -0.119 & $* *$ & -0.181 & $* * *$ \\
\hline 13. Women board & 0.136 & 0.100 & 0.148 & $* * *$ & 0.250 & $* * *$ & 0.198 & $* *$ & 0.097 & $* *$ & -0.086 & + & 0.114 & $* *$ \\
\hline $\begin{array}{l}\text { 14. FamilyWomen } \\
\text { board }\end{array}$ & 0.022 & 0.048 & -0.073 & + & 0.013 & & -0.101 & $*$ & 0.376 & $* * *$ & -0.089 & $*$ & -0.041 & \\
\hline $\begin{array}{l}\text { 15. Independent } \\
\text { Women board }\end{array}$ & 0.106 & 0.089 & 0.219 & $* * *$ & 0.291 & $* * *$ & 0.288 & $* * *$ & -0.055 & & -0.089 & $*$ & 0.185 & $* * *$ \\
\hline 16. Other Women & 0.008 & 0.030 & -0.033 & & -0.042 & & -0.07 & & -0.141 & $* * *$ & 0.114 & $* *$ & -0.094 & $* *$ \\
\hline
\end{tabular}

Significance levels are based on a two-tailed test $+: \mathrm{p}<0.1 ; *: \mathrm{p}<0.05 ; * *: \mathrm{p}<0.01 ; * * *: \mathrm{p}<0.001$ 
Table 1: Mean, standard deviations, and zero-order correlations (cont.).

\begin{tabular}{|c|c|c|c|c|c|c|c|c|c|c|c|c|c|c|c|c|c|}
\hline & 7 & & 8 & & 9 & & 10 & & 11 & & 12 & & 13 & & 14 & 15 & 16 \\
\hline 7. ROA & 1 & & & & & & & & & & & & & & & & \\
\hline 8. Firm age & 0.074 & $*$ & 1 & & & & & & & & & & & & & & \\
\hline 9. Age Women & -0.069 & + & 0.093 & $*$ & 1 & & & & & & & & & & & & \\
\hline $\begin{array}{l}\text { 10. Tenure } \\
\text { Women }\end{array}$ & -0.012 & & 0.147 & $* * *$ & 0.408 & $* * *$ & 1 & & & & & & & & & & \\
\hline 11. Indepen. board & 0.001 & & 0.137 & $* * *$ & 0.042 & & -0.013 & & 1 & & & & & & & & \\
\hline 12. Family board & -0.035 & & 0.119 & $* *$ & 0.099 & $*$ & 0.169 & $* * *$ & -0.492 & $* * *$ & 1 & & & & & & \\
\hline 13. Women board & 0.234 & $* * *$ & 0.272 & $* * *$ & 0.017 & & -0.006 & & 0.101 & $* *$ & 0.035 & & 1 & & & & \\
\hline $\begin{array}{l}\text { 14. FamilyWomen } \\
\text { board }\end{array}$ & 0.105 & $* * *$ & 0.237 & $* * *$ & -0.023 & & 0.233 & $* * *$ & -0.205 & $* * *$ & 0.463 & $* * *$ & 0.440 & $* * *$ & 1 & & \\
\hline $\begin{array}{l}\text { 15. Independent } \\
\text { Women board }\end{array}$ & 0.156 & $* * *$ & 0.178 & $* * *$ & 0.090 & $*$ & -0.074 & + & 0.215 & $* * *$ & -0.188 & $* * *$ & 0.828 & $* * *$ & -0.04 & 1 & \\
\hline 16. Other Women & 0.152 & $* * *$ & -0.011 & & -0.139 & $* * *$ & -0.216 & $* * *$ & 0.038 & & -0.077 & $*$ & 0.177 & $* * *$ & -0.02 & -0.126 & *** 1 \\
\hline
\end{tabular}

Significance levels are based on a two-tailed test $+: \mathrm{p}<0.1 ; *: \mathrm{p}<0.05 ; * *: \mathrm{p}<0.01 ; * * *: \mathrm{p}<0.001$ 
Table 2. The impact of women directors on CSR

Significance levels are based on a two-tailed test + : $p<0.1 ; *$ : $<<0.05 ; * *: p<0.01 ; * * *$ : $<0.001$

\begin{tabular}{lrrrrrr}
\hline & \multicolumn{1}{l}{ CSR } & & Community & Employee & \\
\hline Family Ownership & -7.704 & $* *$ & -4.798 & -7.839 & $* *$ \\
\hline Firm Size & 1.547 & $* *$ & 0.575 & 1.767 & $* * *$ \\
\hline ROA & 12.67 & $*$ & -0.046 & $*$ & 0.011 & \\
\hline Firm Age & -0.024 & 16.84 & + & 9.345 & \\
\hline Family Directors & -6.597 & -2.164 & -7.142 & \\
\hline independent Directors & 4.161 & 8.337 & 3.447 & \\
\hline Age Women Directors & 0.121 & 0.159 & & 0.064 & \\
\hline Tenure Women Directors & 0.214 & + & 0.241 & & 0.078 & \\
\hline Women Directors & $\mathbf{1 8 . 1 4}$ & $* *$ & $\mathbf{3 1 . 9 7}$ & $* * *$ & $\mathbf{2 1 . 9 3}$ & $* *$ \\
\hline
\end{tabular}

\begin{tabular}{lrlrlrl}
\hline Manufacturing & 9.02 & $* * *$ & 2.51 & 9.51 & $* * *$ \\
\hline $\begin{array}{l}\text { Transport, } \\
\text { communications }\end{array}$ & 7.91 & $* *$ & 5.83 & 8.82 & $* * *$ \\
\hline Wholesalers and retailers & 10.34 & $* * *$ & 6.72 & + & 10.14 & $* * *$ \\
\hline Finance and insurance & 2.09 & 1.80 & -0.28 & \\
\hline Services & 11.30 & $* * *$ & 6.55 & 11.74 & $* * *$ \\
\hline & & & & & & \\
\hline Wald & 90.50 & $* * *$ & 64.53 & $* * *$ & 73.92 & $* * *$ \\
\hline R squared & 0.240 & 0.13 & 0.2 & \\
\hline N obs & 416 & 528 & 529 & \\
\hline
\end{tabular}


Table 3. The impact of women directors' type on CSR

CSR Community Employee

\begin{tabular}{lrlrrrr}
\hline Family ownership & -9.811 & $* * *$ & -6.367 & $*$ & -10.411 & $* * *$ \\
\hline Firm Size & 1.657 & $* *$ & 0.383 & 1.646 & $* * *$ \\
\hline ROA & 12.69 & $*$ & -0.039 & 8.925 & \\
\hline Firm Age & -0.024 & 17.97 & 0.009 & \\
\hline Family Directors & -9.517 & -2.046 & -10.96 & $*$ \\
\hline Independent Directors & 5.127 & 9.807 & 3.804 & \\
\hline Age Women Directors & 0.135 & 0.149 & 0.079 & \\
\hline Tenure Women Directors & 0.164 & 0.173 & -0.017 & \\
\hline Family Insider Directors & 63.88 & $* *$ & 67.12 & $*$ & 54.54 & $*$ \\
\hline Family outsider Directors & 23.89 & 12.40 & 42.90 & $*$ \\
\hline Non-Family Insider Directors & 5.102 & -2.580 & -17.66 & \\
\hline Non-Family Outsider Directors & 16.73 & $* *$ & 32.55 & $* * *$ & 19.91 & $* *$ \\
\hline
\end{tabular}

\begin{tabular}{|c|c|c|c|c|c|c|}
\hline Manufacturing & 9.125 & $* * *$ & 3.062 & & 9.872 & $* * *$ \\
\hline Transport, communications & 7.953 & $* *$ & 7.182 & + & 9.215 & $* * *$ \\
\hline Wholesalers and retailers & 10.35 & $* * *$ & 6.778 & + & 10.81 & $* * *$ \\
\hline Finance and insurance & 2.465 & & 2.163 & & 0.552 & \\
\hline Services & 11.49 & $* * *$ & 7.522 & $*$ & 12.86 & $* * *$ \\
\hline Wald & 105.2 & $* * *$ & 87.40 & $* * *$ & 81.00 & $* * *$ \\
\hline R squared & 0.21 & & 0.15 & & 0.21 & \\
\hline Nobs & 416 & & 528 & & 529 & \\
\hline
\end{tabular}

Significance levels are based on a two-tailed test + : $\mathrm{p}<0.1 ; *: \mathrm{p}<0.05 ; * *: \mathrm{p}<0.01 ; * * *: \mathrm{p}<0.001$ 
Table 4. The effect of having at least one woman director of each type on CSP

CSR Community Employee

\begin{tabular}{|c|c|c|c|c|c|c|}
\hline Family Ownership & -8.130 & $* * *$ & -4.120 & & -7.999 & $* *$ \\
\hline Firm Size & 1.743 & $* *$ & 0.454 & & 1.600 & $* * *$ \\
\hline ROA & 14.79 & * & 21.07 & ** & 11.08 & \\
\hline Firm Age & -0.018 & & -0.034 & & 0.012 & \\
\hline Age Women Directors & 0.126 & & 0.163 & & 0.044 & \\
\hline Tenure Women Directors & 0.160 & & 0.158 & & 0.046 & \\
\hline Family Directors & -5.142 & & 1.328 & & -5.691 & \\
\hline independent Directors & 6.155 & & 12.20 & $*$ & 4.381 & \\
\hline At least one Women Family insider & 4.150 & $* *$ & 5.638 & $* *$ & 4.093 & $*$ \\
\hline At least one Women Family Outsider & 0.595 & & 0.553 & & 0.131 & \\
\hline $\begin{array}{l}\text { At least one Women Non family } \\
\text { insider }\end{array}$ & 1.764 & & 0.320 & & 3.082 & \\
\hline $\begin{array}{l}\text { At least one Women Non family } \\
\text { outsider }\end{array}$ & 3.171 & ** & 5.391 & ** & 5.971 & ** \\
\hline Manufacturing & 9.103 & $* * *$ & 2.999 & & 9.698 & $* *$ \\
\hline Transport, communications & 7.809 & $* *$ & 6.922 & & 9.470 & $*$ \\
\hline Wholesalers and retailers & 10.83 & $* *$ & 7.588 & + & 10.86 & * \\
\hline Finance and insurance & 1.964 & & 2.501 & & 0.528 & \\
\hline Services & 11.47 & *** & 7.425 & + & 12.56 & $* *$ \\
\hline
\end{tabular}

\begin{tabular}{|c|c|c|c|c|c|c|}
\hline Wald & 84.04 & $* * *$ & 51.88 & $* * *$ & 59.80 & $* * *$ \\
\hline R2 & 0.200 & & 0.110 & & 0.190 & \\
\hline Nobs & 416 & & 528 & & 529 & \\
\hline
\end{tabular}

Significance levels are based on a two-tailed test + : $\mathrm{p}<0.1 ; *: \mathrm{p}<0.05 ; * *: \mathrm{p}<0.01 ; * * *: \mathrm{p}<0.001$ 